\title{
Absenteeism and the Technical Safety Index of a tertiary hospital nursing team*
}

\author{
Absenteísmo e índice de segurança técnica da equipe de enfermagem de um hospital terciário \\ Absentismo e índice de seguridad técnica del equipo de enfermería de un hospital terciario
}

How to cite this article:

Trettene AS, Razera APR, Beluci ML, Prado PC, Mondini CCSD, Spiri WC. Absenteeism and the Technical Safety Index of a tertiary hospital nursing team. Rev Esc Enferm USP. 2020;54:e03585. doi: https://doi.org/10.1590/S1980-220X2018036003585

\section{Armando dos Santos Trettene $e^{1,2,3}$ \\ Ana Paula Ribeiro Razera ${ }^{3}$ \\ Marli Luiz Beluci ${ }^{4}$ \\ Priscila Capelato Prado \\ Cleide Carolina da Silva Demoro Mondini $^{5}$ \\ Wilza Carla Spiri ${ }^{1}$}

* Extracted from the Post-doctoral work: "Absenteísmo da equipe de enfermagem de um hospital especializado: subsídios para o cálculo do Índice de Segurança Técnica”, PróReitoria de Pesquisa, Universidade Estadual Paulista "Júlio de Mesquita Filho”, 2018.

${ }^{1}$ Universidade Estadual Paulista "Júlio de Mesquita Filho”, Programa de Pós-Graduação em Enfermagem, Botucatu, SP, Brazil.

${ }^{2}$ Universidade de São Paulo, Hospital de Reabilitação de Anomalias Craniofaciais, Programa de Pós-Graduação em Ciências da Reabilitação, Bauru, SP, Brazil.

${ }^{3}$ Universidade Paulista, Departamento de Enfermagem, Bauru, SP, Brazil.

${ }^{4}$ Centro Universitário de Adamantina, Departamento de Enfermagem, Adamantina, SP, Brazil.

${ }^{5}$ Universidade de São Paulo, Hospital de Reabilitação de Anomalias Craniofaciais, Departamento de Enfermagem, Bauru, SP, Brazil.

\section{ABSTRACT}

Objective: To identify the nursing team absenteeism rate, calculate the Technical Safety Index and compare them to the percentage established by the Federal Nursing Council. Method: A descriptive, analytical, and retrospective study which included nursing professionals working in a public and tertiary hospital. The Human Resources Department database of the Institution was used for data collection. Absenteeism was considered as any unplanned absence. Results: Ninety-nine (99) professionals participated, of which 21 were nurses and 78 were nursing technicians. Weekly days off prevailed among the expected absences, with $17 \%$ for both categories. Maternity leave prevailed among nurses and medical leave among nursing technicians regarding absenteeism, with averages of $12 \%$ and $9 \%$, respectively. The Technical Safety Index was $42 \%$ for nurses and $38 \%$ for nursing technicians. Conclusion: The nursing team's absenteeism rate was $21.5 \%$, while the Technical Safety Index was $40 \%$, thus constituting higher values than those established by the Federal Nursing Council.

\section{DESCRIPTORS}

Absenteeism; Nursing Team; Nursing Staff, Hospital; Personnel Administration, Hospital; Management Indicators. 


\section{INTRODUCTION}

The managerial dimension constitutes an essential part of the nursing work process, because the nurse plans and implements actions from it aimed at care quality such as favorable working conditions, including forecasting and providing human resources ${ }^{(1-2)}$.

Efficient use of resources is widely discussed as a way to reduce costs in institutions. The nursing team occupies a prominent place among health professionals since it represents the largest number of staff. Thus, both material and human resources tend to be compromised when the need to optimize spending emerges. In this sense, the nursing staff is often affected ${ }^{(2-3)}$.

Although a lack of material resources limits working conditions, both the quantitative and qualitative damage resulting from inadequate human resources compromises the quality of care to a greater extent ${ }^{(4)}$.

A deficit in staffing increases the nursing workload, contributing to the occurrence of iatrogenic conditions such as healthcare-related infections, pressure injuries, and increased hospitalization time, with a consequent increase in total costs. Moreover, such a deficit can create occupational risks, as job demands become high and the decision-making margin low, leading to psychological stress ${ }^{(5-6)}$.

In contrast, the ideal number of professionals positively affects management and care indicators, providing care quality, safety to patients and professionals, and improvements in the work environment ${ }^{(7-8)}$. Thus, proper nursing staff sizing becomes indispensable, as it enables adjusting the team to the patients' needs, in addition to preventing work overload ${ }^{(2,9)}$.

In this context, different methodologies have been proposed aiming to properly determine the size of the nursing professional team. In Brazil, the Federal Nursing Council (Cofen) presents Resolution 543 of 2017 as its guideline, which is based on the Patient Classification System to indicate the minimum hours of care and the percentage distribution of nursing professionals for each type of care, including: minimal, intermediate, semi-intensive, high dependency and intensive care ${ }^{(10)}$.

However, it is noteworthy that the current legislation regarding nursing team sizing has been slowly incorporated into clinical practice, i.e. the number of nursing professionals is below what is considered ideal ${ }^{(2,11)}$.

The health service, the nursing service and the profile of the attended patients must be considered in order to adequately size the nursing team. Other variables must also be considered, including the absenteeism percentage ${ }^{(10)}$.

Absenteeism is the term used to characterize non-attendance to work or other social obligations. The multifactorial etiology reflects its complexity and is currently considered an important managerial indicator. However, it is admittedly a problem which is difficult to control, as well as poorly monitored, which is a challenge for managers ${ }^{(12-13)}$. It causes damage to both patients and workers, compromising the care quality, the safety of patients and professionals, overloading the other team members and burdening the institutions ${ }^{(14-15)}$.
Another variable to be considered in the staffing size is the Technical Safety Index (TSI), which refers to the percentage to be added to the number of nursing professionals according to the professional category in order to ensure coverage of planned or unplanned absences ${ }^{(10)}$.

Although Cofen presents a minimum value of $15 \%$ for TSI, it advises that the calculation should be individualized, respecting the specificities of the different work processes of nursing teams ${ }^{(10)}$. In fact, investigations have pointed out discrepancies in values, reinforcing the need for managers to calculate this index in their care realities aiming for actual staff sizing ${ }^{(16-18)}$. Therefore, in addition to the absenteeism of nursing professionals, determining TSI has been monitored as a managerial indicator of human resources ${ }^{(19)}$.

Given the above, one sought to answer the following questions: what is the absenteeism percentage of nursing professionals working in a public and tertiary hospital? What is the TSI of the nursing team? Are the absenteeism percentage and TSI in accordance with those recommended by Cofen?

Considering the problem of absenteeism in health institutions, as well as its implications in the work process and patient safety in reflecting an unfavorable environment for nursing care, it is indispensable to identify it, including its etiology, and then to calculate the TSI based on this situational diagnosis which reflects the real needs, favoring an assertive staff sizing.

Thus, the objectives of this investigation were: to identify the nursing staff absenteeism rate, to calculate the TSI and to compare them with the respective percentages established by Cofen.

\section{METHOD}

\section{STUdDY DESIGN}

A descriptive, analytical, retrospective, and quantitative study.

\section{SCENARIO}

The study was performed in a 91-bed public and tertiary hospital located in the interior of São Paulo state, Brazil. This hospital is recognized by national and international bodies for the excellent service it provides to the population in different areas, including healthcare, teaching and research aimed at patients with craniofacial anomalies and related syndromes. The Hospital Department is composed of the following sections: Ambulatory, Surgical Center (SC) and Central Sterile Services Department (CSSD), Intensive Care Unit (ICU), Semi-Intensive Care Unit (SICU) and Inpatient Unit (IU).

\section{Population}

The population comprised nursing professionals including nurses and nursing technicians. No inclusion or exclusion criteria were established for this study. Thus, the sample included the entire population of 99 professionals, constituting 21 nurses and 78 nursing technicians. 
It is noteworthy that the professional hiring in the scenario institution of this study occurs exclusively through public tender. The professionals work under the Consolidation of Labor Laws (CLT - Consolidação das Leis do Trabalho) with a weekly workload of 36 hours and consequently a weekly break. The performance takes place on duty, meaning there are four teams: morning, afternoon, even nights and odd nights. Six annual breaks are granted in addition to the weekly breaks based on domestic legislation.

\section{Data collection}

The Human Resources Department database of the Institution was used for data collection. One considered the records for the period from January 1 to December 31, 2016.

Days of absences related to excused or unjustified absences, medical leave, maternity, paternity, work accident, death of a first-degree relative, marriage, granted leave, leave for participation in training and development programs, judicial summons, blood donation, linked to electoral justice, for participation in public order activities such as commissions and for judging competitions (among others) were considered as reasons for absenteeism. These types of absences behaved as random variables because they occur on any day of the year. For the purpose of evaluating these indicators, the number of absences per professional category was identified monthly and the absenteeism rate of the professionals was then calculated.

One considered the absenteeism percentage (unplanned absences) and the percentage of planned absences for the TSI calculation, which included paid weekly days off according to the weekly workload, coverage of holidays not coinciding with Sundays and holidays. It is noteworthy that although the CLL legislation guarantees 30 days of vacation in the year, it allows a 10-day cash allowance, meaning that there is the possibility of the worker to convert $1 / 3$ of the vacation days into cash, and using the other 20 days.

The following parameters were adopted in order to compare the results: absenteeism rates of $6.7 \%$ and TSI of $15 \%{ }^{(10)}$. The equations arranged in Chart 1 were used for the calculations ${ }^{(16)}$.

Chart 1 - Equations used to calculate different types of absences and the Technical Safety Index - Bauru, SP, Brazil, 2017.

\begin{tabular}{|c|c|}
\hline $\begin{array}{c}\text { Absences for weekly days off (E\%): } \\
E \%=\frac{e}{D-e} \cdot 100 \\
\text { In which: } \\
\mathrm{E} \%=\text { percentage of days off. } \\
\mathrm{e}=\text { number of days off, per week, nursing workers. } \\
\mathrm{D}=\text { number of working days in the unit. }\end{array}$ & $\begin{array}{c}\text { Absences for vacation }\left(\mathrm{V}_{\mathrm{k}} \%\right) \text { : } \\
V_{k} \%=\frac{V_{k}}{D-V_{k}} \cdot 100 \\
\text { In which: } \\
\mathrm{V}_{\mathrm{k}} \%=\text { percentage of vacation, according to professional category }{ }_{\mathrm{k}} \\
\text { (nursing technicians and assistants). } \\
\mathrm{V}_{\mathrm{k}}=\text { average vacation days, professional category } \\
\mathrm{D}=\text { days in the year, } 365 \text { days. }\end{array}$ \\
\hline $\begin{array}{l}\text { Absences due to holidays not coinciding with Sundays (F\%): } \\
\qquad \begin{array}{l}\qquad \%=\frac{f}{D-f} \cdot 100 \\
\quad \text { In which: } \\
\mathrm{V} \%=\text { percentage of vacation days. } \\
\mathrm{v}=\text { vacation days in the year. } \\
\mathrm{D}=\text { days in the year, } 365 \text { days. }\end{array}\end{array}$ & $\begin{array}{c}\begin{array}{c}\text { Unplanned absences } \\
\text { (for absenteeism }-\mathrm{A}_{\mathrm{k}} \% \text { ): }\end{array} \\
A_{k} \%=\left(\frac{\sum_{i} a_{k, i}}{D-\sum_{i} a_{k, i}}\right) \cdot 100 \\
\text { In which: }\end{array}$ \\
\hline IST $\%=\left\{\left[\left(1+\frac{E \%}{100}\right) \cdot\left(1+\frac{F}{1}\right.\right.\right.$ & $\begin{array}{l}\text { Index (TSI\%): } \\
\left.\left.\left.1+\frac{V_{k} \%}{100}\right) \cdot\left(1+\frac{A_{k} \%}{100}\right)\right]-1\right\} \cdot 100\end{array}$ \\
\hline
\end{tabular}

Source: Rogenski and Fugulin, 2007 ${ }^{(16)}$.

The Microsoft Excel program version 2015 was used for organizing the data. The spreadsheet was organized to record absences in days. Therefore, records made available in hours were counted to correspond to one working day. All records for 2016 were included. The data collection and organization period was from June to September 2017. The Spearman Correlation, Mann-Whitney and the KruskalWallis Analysis of Variance were used for statistical analysis. A significance level of $5 \%$ was considered for all tests $(\mathrm{p} \leq 0.05)$.

\section{ETHICAL ASPECTS}

Data collection began after approval by the Institution's Ethics Committee in Research through opinion no. 2.096.162/17 in 2017. It is noteworthy that the methodology used in this research, which comprised the Human Resources Department database of the Institution and is therefore a secondary data source, made using an Informed Consent form unfeasible. However, a Term of Commitment was formalized in accordance with the ethical precepts of Resolution 466/12 of the National Health Council. 


\section{RESULTS}

The sample comprised 99 nursing professionals, of which 21 were nurses and 78 were nursing technicians. The average age among nurses was 47.7 years, with a predominance of females $(n=20)$, working in the inpatient unit $(n=9)$, during the daytime $(n=17)$. Regarding education, there was equity between those with specialization and Master's degrees (both $n=9)($ Table 1$)$.
The average age regarding nursing technicians was 45.3 years, with a predominance of females $(n=71)$, working in the Surgical Center and in the Inpatient Unit (both $\mathrm{n}=22)$, during the daytime $(\mathrm{n}=57)$. Regarding education, those with high school level prevailed $(\mathrm{n}=$ 61) (Table 1). It was also evident that none of the sociodemographic variables influenced absenteeism in either category (Table 1).

Table 1 - Distribution of nurses and nursing technicians according to the variables: gender, education, work shift and action unit Bauru, SP, Brazil, 2017.

\begin{tabular}{|c|c|c|c|c|c|}
\hline Variables & & $N(n \%)$ & P-value & NT (n \%) & P-value \\
\hline \multirow{2}{*}{ Gender $^{*}$} & Female & $20(95.0)$ & \multirow{2}{*}{--- } & $71(91.0)$ & \multirow{2}{*}{0.34} \\
\hline & Male & $1(5.0)$ & & $7(9.0)$ & \\
\hline \multirow{5}{*}{ Education level ${ }^{*}$} & Specialization & $9(43.0)$ & \multirow{5}{*}{0.43} & & \multirow{5}{*}{0.13} \\
\hline & Master's & $9(43.0)$ & & & \\
\hline & Doctorate & $3(14.0)$ & & & \\
\hline & High school & & & $61(78.0)$ & \\
\hline & Higher education & & & $17(22.0)$ & \\
\hline \multirow{2}{*}{ Workshift" } & Day & $17(81.0)$ & \multirow{2}{*}{0.08} & $57(73.0)$ & \multirow{2}{*}{0.42} \\
\hline & Night & $4(19.0)$ & & $21(27.0)$ & \\
\hline \multirow{2}{*}{ Other employment ${ }^{*}$} & Yes & $18(86.0)$ & \multirow{2}{*}{0.20} & $21(27.0)$ & \multirow{2}{*}{0.71} \\
\hline & No & $3(14.0)$ & & $57(73.0)$ & \\
\hline \multirow{4}{*}{ Work unit ${ }^{\&}$} & IU & $9(43.0)$ & \multirow{4}{*}{0.14} & $22(28.0)$ & \multirow{4}{*}{0.06} \\
\hline & SC and CSSD & $5(24.0)$ & & $35(45.0)$ & \\
\hline & ICU and SICU & $5(24.0)$ & & $18(23.0)$ & \\
\hline & Ambulatory & $2(9.0)$ & & $3(4.0)$ & \\
\hline
\end{tabular}

N: Nurses. NT: Nursing technicians. IU: Inpatient Unit. SC: Surgical Center. CSSD: Central Sterile Services Department. ICU: Intensive Care Unit. SICU: SemiIntensive Care Unit. ${ }^{*}$ Mann-Whitney test. ${ }^{\circledR}$ Kruskal-Wallis Analysis of Variance. Significance level of $5 \%$ ( $\left.\mathrm{p} \leq 0.05\right)$.

Weekly days off prevailed among the expected absences, totaling $17 \%$ for both categories. Regarding vacations and considering the adherence to the monetary allowance, the average for nurses was 28 days per year for each professional, while it was 25 days for nursing technicians. When considering the percentage of total expected absences, prevalence was identified among nurses (28\%) compared to nursing technicians (27\%) (Table 2).

Table 2 - Average annual percentage of expected absences, including: weekly days off, non-coinciding Sunday holidays and vacation days by professional category - Bauru, SP, Brazil, 2017.

\begin{tabular}{lcc}
\hline Variables & Nurses (\%) & $\begin{array}{c}\text { Nursing } \\
\text { technicians (\%) }\end{array}$ \\
\hline Absences due to weekly days off & 17.0 & 17.0 \\
Absences due to vacation & 8.0 & 7.0 \\
$\begin{array}{l}\text { Absences for non-coinciding } \\
\text { holidays with Sundays }\end{array}$ & 3.0 & 3.0 \\
\hline Total & $\mathbf{2 8 . 0}$ & $\mathbf{2 7 . 0}$ \\
\hline
\end{tabular}

Maternity leave for nurses (4\%) and medical leave for nursing technicians $(6 \%)$ prevailed among unplanned absences. In comparing the total average days between professional categories, there was a predominance of nurses (12\%) (Table 3).
Table 3 - Average values of absenteeism days (unplanned absences) by professional category - Bauru, SP, Brazil, 2017.

\begin{tabular}{lcc}
\hline Variables & Nurses (\%) & $\begin{array}{c}\text { Nursing } \\
\text { technicians (\%) }\end{array}$ \\
\hline $\begin{array}{l}\text { Absenteeism due to maternity } \\
\text { leave }\end{array}$ & 4.0 & 0.1 \\
$\begin{array}{l}\text { Absenteeism due to medical } \\
\text { leave }\end{array}$ & 4.0 & 6.0 \\
$\begin{array}{l}\text { Absenteeism due to granted } \\
\text { leave }\end{array}$ & 1.3 & 2.5 \\
$\begin{array}{l}\text { Absenteeism due to paid leave } \\
\text { Absenteeism due to INSS (work } \\
\text { accident/injury) leave }\end{array}$ & 1.2 & --- \\
$\begin{array}{l}\text { Absenteeism due to other types } \\
\text { of absences }\end{array}$ & 1.0 & 0.3 \\
\hline Total & 0.5 & 0.1 \\
\hline
\end{tabular}

The percentage of absenteeism among nurses was $12 \%$, prevailing over nursing technicians (9\%). The TSI was higher among nurses (42\%) compared to nursing technicians (38\%). Absenteeism and TSI values were higher than the values stipulated by Cofen (Figures 1 and 2). 
Mean percentages of absenteeism

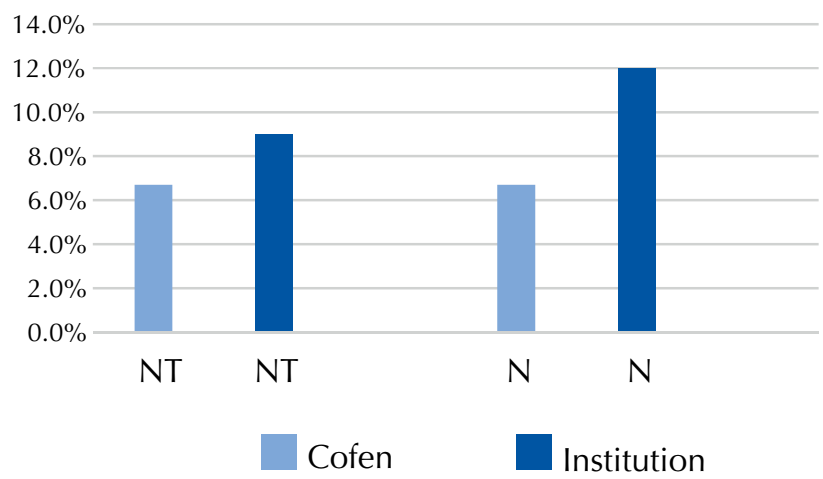

Figure 1 - Mean percentages of nursing staff absenteeism compared to those stipulated by the Federal Nursing Council Bauru, SP, Brazil, 2017.

Mean percentages of the Technical Security Index

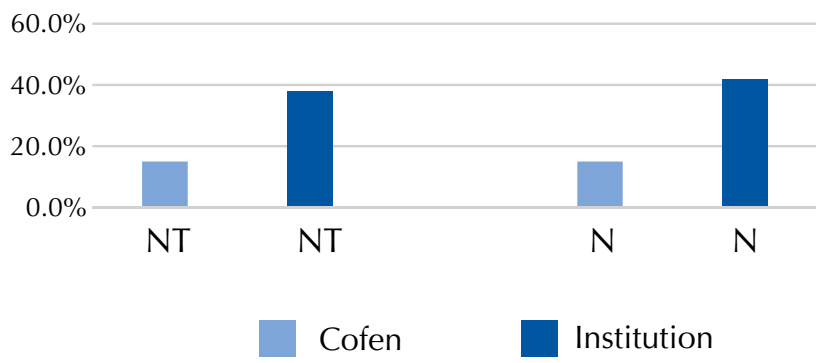

Figure 2 - Mean percentages of the Technical Security Index of the nursing staff compared to those stipulated by the Federal Nursing Council - Bauru, SP, Brazil, 2017.

\section{DISCUSSION}

In the present study, one sought to correlate absenteeism with sociodemographic and labor factors. However, no significant correlations were observed for either nurses or nursing technicians, contrary to the findings in the literature $^{(5,11,17,20-21)}$. The etiological factors of absenteeism are complex and multifactorial, and include but are not limited to: age, gender, education, function, work shift, workplace, training time, length of service in the institution, level of responsibility, work process, unfavorable conditions, fragile interpersonal and hierarchical relationship, dehumanization, double working hours, low salary, married employees and having children of non-school age, unhealthy duties, ergonomic and emotional problems $s^{(5,11,17,20-21)}$.

Regarding the planned absences, paid weekly days off prevailed for both nurses and nursing technicians. Their percentages were in accordance with those established by Cofen for professionals with a weekly workload of 36 hours, $16.6 \%$ referring to days off and $3.4 \%$ for holidays not coinciding with Sunday ${ }^{(10)}$. Research conducted in different institutional realities highlighted paid time off among the planned absences $^{(16,18)}$.

A study using a qualitative and quantitative methodology showed that the percentages related to unplanned absences were lower than those of planned absences, contrary to what was reported by nurses who pointed out unplanned absences as the main reason for numerical inadequacy of nursing professionals ${ }^{(16)}$. It is noteworthy that the coverage of paid time off is considered for calculating staff sizing ${ }^{(10)}$.

Maternity leave prevailed regarding unplanned absences among nurses. This result is explained by the granting of 180 days of this license in the scenario institution of this study, which is different from others which normally grant 120 days. Another fact to be considered refers to the maternity leave of two nurses during the study period, i.e. approximately $10 \%$ of the total of nursing professionals. A similar result was observed in another study ${ }^{(16)}$.

Medical leave prevailed among nursing technicians as an unplanned absence, thus corroborating the literature ${ }^{(16-18)}$. However, it is remarkable that although the main cause of absenteeism was maternity leave among nurses, it was followed by medical leave. It is inferred that this finding is related to the unfavorable work environment to which health professionals are exposed, including the nursing staff, where they are vulnerable to physical and psychological violence, whose negative repercussions certainly affect health ${ }^{(22)}$.

Different investigations have pointed to a predominance of absenteeism due to medical leave among nursing professionals, with diseases of the musculoskeletal system and connective tissue, followed by mental and behavioral disorders being predominant ${ }^{(19,23-24)}$. Depression, anxiety and stress stand out among the mental and psychological disorders ${ }^{(25)}$. Therefore, medical leave is the main reason for absenteeism of the nursing team, deserving attention from managers and researchers ${ }^{(19,23-25)}$.

It was found that absenteeism predominated among nurses (12\%) compared to nursing technicians (9\%). Similar results were evidenced in another study, which included the nursing team of a university hospital in the Midwest region of Brazil, where the percentage of unplanned absences among nurses was $43 \%$ against $13 \%$ among technicians and nursing assistants ${ }^{(17)}$.

In contrast, another investigation which included 613 nursing professionals from the University Hospital of the Universidade de São Paulo, found an average absenteeism rate of $5.6 \%$ for nurses and $9.7 \%$ for nursing technicians/ assistants $^{(19)}$.

Other studies indicate a prevalence of absenteeism among nursing technicians, associating this finding with the activities developed by the category ${ }^{(17,19,26-27)}$. One study, which included 59 nursing professionals working in the Intensive Care Unit of a public and tertiary hospital, showed average absenteeism rates of $9.41 \%$ among nurses and $12.52 \%$ among nursing technicians ${ }^{(26)}$. Another study conducted in a large public hospital found an absenteeism rate of $5.6 \%$ for nurses and $9.7 \%$ for nursing technicians/ assistants ${ }^{(17)}$. A study which evaluated absenteeism of the nursing team of three public hospitals in São Paulo showed that the annual percentage among nurses was $7.2 \%$, while it was $10.8 \%$ for nursing technicians ${ }^{(27)}$. Yet another study conducted in a public and university hospital showed an absenteeism rate of $5.6 \%$ for nurses and $9.7 \%$ for nursing technicians/assistants ${ }^{(19)}$.

It was also identified that absenteeism was higher than recommended by Cofen in both professional categories ${ }^{(10)}$. 
Aging workers, stability and longer maternity leave for employees working in public institutions may justify this finding ${ }^{(21)}$. For example, the average age of nursing professionals in this study was 46.5 years.

In sum, the different absenteeism percentages, as well as their values being higher than those stipulated by Cofen, reflect its complexity and point to the need for its monitoring in each institutional reality.

The TSI of nurses was $42 \%$ and that of nursing technicians was $38 \%$. In comparing the TSI obtained in this study to the one stipulated by Cofen (15\%), it was observed that they were superior in both professional categories. Permission for additional days off such as granted days (six per year), and those in the hour bank since overtime is not paid, as well as the 180-day maternity leave, certainly contributed to the increase in absenteeism and consequently of TSI. In this sense, the literature indicates a greater number of absence among public servants compared to the hired workers ${ }^{(21)}$.

Corroborating the findings of this study, an investigation which evaluated the TSI of the pediatric nursing team of a public teaching hospital for five years found that the average value among nurses was $37.58 \%$, ranging from 27.4 and $44.7 \%$. Furthermore, the average for nursing technicians was $36.54 \%$, ranging from 31.8 to $40.4 \%{ }^{(16)}$. Another investigation carried out with professionals from the nursing team of the clinical units of a public and university hospital pointed out a TSI of $70.4 \%$ for nurses and $66.1 \%$ for technicians and assistants ${ }^{(26)}$, which are much higher than those found herein. Another study, which included nursing technicians and assistants in a emergency unit of a public and university hospital, pointed out a TSI of $51 \%{ }^{(18)}$.

It is emphasized that consideration on which methods to use to quantify the nursing workload, as well as the control and mastery over the employed methodologies are indispensable. Managers' arguments with administration regarding the adequacy of staff should be substantiated and the medium and long-term benefits emphasized ${ }^{(2,28)}$. Thus, identifying and monitoring absenteeism and consequently TSI becomes indispensable, constituting an important managerial indicator.
Finally, it is believed that this investigation enabled identifying absenteeism and the TSI of the nursing team, as well as the main factors for their determination, providing parameters for the decision-making process regarding nursing human resources management. The findings of this study reinforce the recommendation to evaluate these variables in each service, considering that they are influenced by the work process as a whole, since they include indispensable subsidies for determining the nursing staff, mainly due to the fact that the values are higher than those recommended by legislation.

As previously discussed, granting paid time off, aging professionals, stability and 180-day maternity leave may justify the higher absenteeism rates and TSI identified in this study. Although these benefits are important achievements for health professionals, managers should pay attention to their care implications in the same proportion, including the amount of staff needed to cover these absences.

Some interventions have been proposed to minimize absenteeism. In this sense, an investigation presented six factors which favor reducing absenteeism, including: flexible working hours, sufficient number of nursing professionals, decreased stress at home and work, adequate working conditions, better salaries, effective communication with superiors and with colleagues, and incentives for workers not to use sick notes ${ }^{(29)}$. Another study highlighted the following as alternatives for reducing absences at work: participative management, teamwork, service organization and therapeutic support ${ }^{(30)}$.

The heterogeneity of the methodologies for calculating absenteeism, as well as the different institutional realities of the studies make it difficult to compare the results, therefore constituting limitations of this study.

\section{CONCLUSION}

The nursing staff absenteeism rate was $21.5 \%$, mainly influenced by maternity leave among nurses and medical leave among nursing technicians, while the Technical Safety Index was $40 \%$. Therefore, the percentages of both variables were higher than the values established by the Federal Nursing Council (Cofen).

\section{RESUMO}

Objetivo: Identificar a taxa de absenteísmo da equipe de enfermagem, calcular o Índice de Segurança Técnica e compará-los ao percentual estabelecido pelo Conselho Federal de Enfermagem. Método: Estudo descritivo, analítico, retrospectivo, que incluiu profissionais de enfermagem, atuantes em um hospital público e terciário. Para a coleta de dados, foi utilizado o banco de dados do Departamento de Recursos Humanos da Instituição. Consideraram-se como absenteísmo as ausências não previstas. Resultados: Participaram 99 profissionais, sendo 21 enfermeiros e 78 técnicos. As folgas semanais prevaleceram entre as ausências previstas, sendo $17 \%$ para ambas as categorias. Quanto ao absenteísmo, prevaleceu a licença maternidade entre enfermeiros e a licença médica entre técnicos de enfermagem, cujas médias foram de 12\% e 9\%, respectivamente. O Índice de Segurança Técnica foi de $42 \%$ para enfermeiros e 38\% para técnicos de enfermagem. Conclusão: A taxa de absenteísmo da equipe de enfermagem foi de 21,5\%, enquanto o Índice de Segurança Técnica foi de 40\%, portanto, superiores aos valores estabelecidos pelo Conselho Federal de Enfermagem.

\section{DESCRITORES}

Absenteísmo; Equipe de Enfermagem; Recursos Humanos de Enfermagem no Hospital; Administração de Recursos Humanos em Hospitais; Indicadores de Gestão.

\section{RESUMEN}

Objetivo: Identificar el índice de absentismo del equipo de enfermería, calcular el Índice de Seguridad Técnica y compararlos al porcentual establecido por el Consejo Federal de Enfermería. Método: Estudio descriptivo, analítico, retrospectivo, que incluye a profesionales enfermeros actuantes en un hospital público y terciario. Para la recolección de datos, se empleó el banco de datos del 
Departamento de Recursos Humanos del Centro. Se consideraron como absentismo las ausencias no previstas. Resultados: Participaron 99 profesionales, siendo 21 enfermeros y 78 técnicos. Los días libres semanales prevalecieron entre las ausencias previstas, siendo el 17\% para ambas categorías. En cuanto al absentismo, prevaleció la licencia de maternidad entre enfermeros y la licencia médica entre técnicos de enfermería, cuyos promedios fueron del 12\% y el 9\%, respectivamente. El Índice de Seguridad Técnica fue del $42 \%$ para enfermeros y del $38 \%$ para técnicos de enfermería. Conclusión: El índice de absentismo del equipo de enfermería fue del 21,5\%, mientras que el Índice de Seguridad Técnica fue del 40\%, por lo tanto, superiores a las cifras establecidas por el Consejo Federal de Enfermería.

\section{DESCRIPTORES}

Absentismo; Grupo de Enfermeira; Personal de Enfermeira en Hospital; Administración de Personal em Hospitais; Indicadores de Gestión.

\section{REFERENCES}

1. Maziero VG, Bernardes A, Spiri WC, Gabriel CS. Building meanings about management assistance: a phenomenological study. Ciênc Cuid Saúde [Internet]. 2014 [cited 2018 July 19];13(3):563-70. Available from: http://www.periodicos.uem.br/ojs/index.php/CiencCuidSaude/ article/view/23245/pdf_342

2. Trettene AS, Fontes CM, Razera AP, Prado PC, Bom GC, Von Kostrisch LM. Sizing of nursing staff associated with self-care promotion in a pediatric semi-intensive care unit. Rev Bras Ter Intensiva [Internet]. 2017 [cited 2018 July 22];29(2):171-9. Available from: http://www. scielo.br/pdf/rbti/v29n2/en_0103-507X-rbti-29-02-0171.pdf

3. Fugulin FMT, Lima AFC, Castilho V, Guimarães CP, Carvalho A, Gaidzinski RR. Nursing staff in the internal medicine and surgical units of teaching hospitals: composition and cost. Rev Esc Enferm USP [Internet]. 2015 [cited 2018 July 22]; 49(Spe2):48-54. Available from: http://www.scielo.br/scielo.php?pid=S0080-62342015000800048\&script=sci_arttext\&tlng=en

4. Hernández-Cruz R, Moreno-Monsiváis MG, Cheverría-Rivera S, Díaz-Oviedo A. Factors influencing the missed nursing care in patients from a private hospital. Rev Latino Am Enfermagem [Internet]. 2017 [cited 2018 July 22];25:e2877. Available from: https://www.ncbi. nlm.nih.gov/pmc/articles/PMC5510998/

5. Bargas EB, Monteiro MI. Factors related to absenteeism due to sickness in nursing workers. Acta Paul Enferm [Internet]. 2014 [cited 2018 July 22];27(6):533-8. Available from: http://www.scielo.br/pdf/ape/v27n6/en_1982-0194-ape-027-006-0533.pdf

6. Mmamma ML, Mothiba TM, Nancy MR. Turnover of professional nurses at Mokopane Hospital in the Limpopo Province, South Africa: experiences of nursing unit managers. Curationis [Internet]. 2015 [cited 2018 July 22];38(2):1566. Available from: http://www.scielo.org. $\mathrm{za} / \mathrm{pdf} / \mathrm{cura} / \mathrm{v} 38 \mathrm{n} 2 / 25 . \mathrm{pdf}$

7. Quadros DV, Magalhães AMM, Mantovani VM, Rosa DS, Echer IC. Analysis of managerial and health care indicators after nursing personnel upsizing. Rev Bras Enferm [Internet]. 2016 [cited 2018 July 22];69(4):638-43. Available from: http://www.scielo.br/pdf/reben/ v69n4/en_0034-7167-reben-69-04-0684.pdf

8. Magalhães AMM, Costa DG, Riboldi CO, Mergen T, Barbosa AS, Moura GMSS. Association between workload of the nursing staff and patient safety outcomes. Rev Esc Enferm USP. 2017;51:e03255. DOI: 10.1590/s1980-220x2016021203255

9. Duclay E, Hardouin JB, Sébille V, Anthoine E, Moret L. Exploring the impact of staff absenteeism on patient satisfaction using routine databases in a university hospital. J Nurs Manag. 2015;23(7):833-41.

10. Conselho Federal de Enfermagem. Resolução COFEN n. 543/17. Atualiza e estabelece parâmetros para o Dimensionamento do Quadro de Profissionais de Enfermagem nos serviços/locais em que são realizadas atividades de enfermagem [Internet]. Brasílçia; 2017 [citado 2018 jul. 22]. Disponível em: http://www.cofen.gov.br/resolucao-cofen-5432017_51440.html/print/

11. Vasconcelos RO, Rigo DFH, Marques LGS, Nicola AL, Tonini NS, Oliveira JLC. Dimensioning of hospital nursing personnel: study with brazilian official parameters of 2004 and 2017. Esc Anna Nery [Internet]. 2017 [cited 2018 July 22];21(4):e20170098. Available from: http://www.scielo.br/pdf/ean/v21n4/1414-8145-ean-2177-9465-EAN-2017-0098.pdf

12. Pasquali S, Capitoni E, Tiraboschi G, Alborghetti A, De Luca G, Di Mauro S. Complexity of care and organizational effectiveness: a survey among medical care units in nine Lombardy region hospitals. Prof Enferm. 2017;70(1):24-30. DOI: 10.7429/pi.2017.701024.

13. Qarani WM, Jan R, Saeed KMI, Khymani L. Challenges on-the-way of nursing administration at public hospitals in Kabul, Afghanistan. J Nurs Manag. 2018;26(4):420-4.

14. Silva Junior FF, Merino EA. Proposal for management of absenteeism among hospital nurses: a systematic review. Acta Paul Enferm [Internet]. 2017 [cited 2018 July 22];30(5):546-53. Available from: http://www.scielo.br/pdf/ape/v30n5/en_0103-2100-ape-30-05-0546.pdf

15. Gaudine A, Saks AM, Dawe D, Beaton M. Effects of absenteeism feedback and goal-setting interventions on nurses' fairness perceptions, discomfort feelings and absenteeism. J Nurs Manag. 2013;21(3):591-602.

16. Rogenski KE, Fugulin FMT. Índice de segurança técnica da equipe de enfermagem da pediatria de um hospital de ensino. Rev Esc Enferm USP [Internet]. 2007 [citado 2018 Jul 22];41(4):683-9. Disponível em: http://www.scielo.br/scielo.php?script=sci_arttext\&pid $=$ S0080-62342007000400020

17. Coelho MA, Fugulin FMT, Cunha CCB, Marques DO. Absenteísmo da equipe de enfermagem das unidades clínicas de um hospital universitário da região centro-oeste do Brasil. Rev Urug Enferm [Internet]. 2016 [citado 2018 jul. 22];11(1):65-75. Disponível em: http:// rue.fenf.edu.uy/index.php/rue/article/view/184/179

18. Campos EC, Juliani CMCM, Palhares VC. O absenteísmo da equipe de enfermagem em unidade de pronto socorro de um hospital universitário. Rev Eletr Enferm [Internet]. 2009 [citado 2018 jul. 22];11(2):295-302. Disponível em: https://www.fen.ufg.br/fen_revista/ v11/n2/pdf/v11n2a09.pdf

19. Sancinetti TR, Soares AVN, Lima AFC, Santos NC, Melleiro MM, Fugulin FMT, et al. Nursing staff absenteeism rates as a personnel management indicator. Rev Esc Enferm USP [Internet]. 2011 [cited 2018 July 22];45(4):1007-12. Available from: http://www.scielo.br/ scielo.php?script=sci_arttext\&pid=S0080-62342011000400031\&lng=en\&nrm=iso\&tlng=en 
20. Carvalho DP, Rocha LP, Barlem JGT, Dias JS, Schallenberger CD. Workloads and nursing workers' health: integrative review. Cogitare Enferm [Internet]. 2017 [cited 2018 July 22];22(1):1-11. Available from: https://revistas.ufpr.br/cogitare/article/view/46569/pdf_en

21. Ferreira RC, Griep RH, Fonseca MJ, Rotenberg L. A multifactorial approach to sickness absenteeism among nursing staff. Rev Saude Publica [Internet]. 2012 [cited 2018 July 22];46(2):259-68. Available from: http://www.scielo.br/pdf/rsp/v46n2/en_3189.pdf

22. Dal Pai D, Sturbelle ICS, Santos C, Tavares JP, Lautert L. Physical and psychological violence in the workplace of healthcare professional. Texto Contexto Enferm [Internet]. 2018 [cited 2018 July 22];27(1):e2420016. Available from: http://www.scielo.br/pdf/tce/v27n1/en_01040707-tce-27-01-e2420016.pdf

23. Marques DO, Pereira MS, Souza ACS, Vila VSC, Almeida CCOF, Oliveira EC. Absenteeism - illness of the nursing staff of a university hospital. Rev Bras Enferm [Internet]. 2015 [cited 2018 July 22];68(5):594-600. Available from: http://www.scielo.br/pdf/reben/v68n5/ en_0034-7167-reben-68-05-0876.pdf

24. Galindo IS, Ferreira SCM, Lazzari DD, Kempfer SS, Testoni AK. Motivos de absenteísmo em uma equipe de enfermagem ambulatorial. J Nursing UFPE on line [Internet]. 2017 [citado 2018 jul. 22];11 Supl. 8:3198-205. Disponível em: https://periodicos.ufpe.br/revistas/ revistaenfermagem/article/view/110184/22064

25. Santana LL, Sarquis LMM, Brev C, Miranda FMD, Felli VEA. Absenteeism due to mental disorders in health professionals at a hospital in southern Brazil. Rev Gaúcha Enferm [Internet]. 2016 [cited 2018 July 22];37(1):e53485. Available from: http://www.scielo.br/pdf/rgenf/ v37n1/en_0102-6933-rgenf-1983-144720160153485.pdf

26. Leitão IMTA, Sousa FSP, Santiago JCS, Bezerra IC, Morais JB. Absenteeism, turnover, and indicators of quality control in nursing care: a transversal study. Online Braz J Nurs [Internet]. 2017 [cited 2018 July 22];16(2):119-29. Available from: http://www.objnursing.uff.br/ index.php/nursing/article/view/5623/pdf

27. Kurcgant P, Passos AR, Oliveira JML, Pereira IM, Costa TF. Absenteeism of nursing staff: decisions and actions of nurse managers. Rev Esc Enferm USP [Internet]. 2015 [cited 2018 July 22];49(n.spe2):35-41. Available from: http://www.scielo.br/scielo.php?script=sci_ arttext\&pid=S0080-62342015000800035\&lng=en\&nrm=iso\&tlng=en

28. Trettene AS, Luiz AG, Razera AP, Maximiano TO, Cintra FM, Monteiro LM. Nursing workload in specialized Semi-intensive Therapy Unit: work force size criteria. Rev Esc Enferm USP [Internet]. 2015 [cited 2018 July 22];49(6):960-6. Available from: http://www.scielo. br/scielo.php?script=sci_arttext\&pid=S0080-62342015000600958\&lng=en\&nrm=iso\&tlng=en

29. Gaudine A, Saks AM, Dawe D, Beaton M. Effects of absenteeism feedback and goal-setting interventions on nurses' fairness perceptions, discomfort feelings and absenteeism. J Nurs Manag. 2013;21(3):591-602.

30. Abreu RMD, Gonçalves RMDA, Simões ALA. Motivos atribuídos por profissionais de uma Unidade de Terapia Intensiva para ausência ao trabalho. Rev Bras Enferm [Internet]. 2014 [citado 2018 jul. 22];67(3):386-93. Disponível em: http://www.scielo.br/pdf/reben/v67n3/00347167-reben-67-03-0386.pdf 